\title{
FROM THE LUNG TO THE BREAST: A YOUNG LADY IN DISTRESS - A CASE REPORT AND LITERATURE REVIEW
}

\author{
$\mathrm{Ng} T H^{1}$, How $S H^{1}$, Kuan $Y C^{1}$, Salmah $B^{2}$ \\ 1 Department of Internal Medicine, International Islamic University Malaysia, Kuantan, Pahang \\ 2 Department of Pathology, Faculty of Medicine, MARA Technology University, Shah Alam, Selangor
}

\section{Correspondence:}

Associate Professor Dr. Ng Teck Han

Kulliyyah of Medicine,

International Islamic University Malaysia,

27510 Kuantan

Pahang, Malaysia.

E-mail: ngteckhan@hotmail.com

Tel: 609-5133710 Ext 3331

Fax 609-5177 631

\begin{abstract}
Metastases to the breast from non-mammary malignant neoplasm are relatively rare. We report a case of metastatic disease to the breast from a primary lung adenocarcinoma in a young 22-year-old lady. Computed tomography of the thorax confirmed right upper lobe mass with multiple lung nodules and a breast lump. The diagnosis of breast metastasis was confirmed by fine needle aspiration cytology of the breast lump with histopathological findings and immunohistochemical features consistent with lung adenocarcinoma. (JUMMEC 2011; 14(2))
\end{abstract}

KEYWORDS: lung cancer, breast metastasis, immunohistochemical staining

\section{Introduction}

Breast cancer is the most common malignancy in women accounting for about $30 \%$ of all female malignancies and the leading cause of death for women ages $35-54$ years (1). Breast metastasis from lung primary is unusual. There was only a handful of cases reporting breast metastasis from lung cancer in the past (1-7). We report a case of metastatic disease to the breast from a primary lung adenocarcinoma in a young 22-year-old lady.

\section{Case report}

A 22-year-old previously healthy married woman, who was a passive smoker, presented to us with 3 days of fever, productive cough with greenish sputum and mild haemoptysis. In the preceding 4 months, she had intermittent dry cough, lethargy with significant loss of appetite and weight. She also had hoarseness of voice for one month and painless left forearm swelling 2 months prior to presentation. The patient was thin, pale and had no clubbing or jaundice. There were multiple hard cervical, submandibular, supraclavicular and posterior auricular lymphadenopathy (the sizes ranged from 0.5 to $2 \mathrm{~cm}$ ). There was no axillary or inguinal lymphadenopathy. There was a non-tender $2 \times 2 \mathrm{~cm}$ bony swelling over the upper one third of the left humerus. The liver was enlarged, 3 $\mathrm{cm}$ below the subcostal margin. There was a discrete, 2 $x 2 \mathrm{~cm}$, non-tender, well circumscribed, firm, and mobile breast lump located at the left upper outer quadrant of the left breast without any associated skin or nipple changes. Clinically, it felt benign. The patient herself was not aware of the breast lump at all. There were no significant findings on lung examination and other systemic examination. Flexible laryngoscopy revealed right vocal cord paralysis.

Investigations revealed hypochromic and normocytic anaemia (haemoglobin $8.5 \mathrm{~g} / \mathrm{dL}$ ) with thrombocytosis (platelet $555 \times 10^{9} / \mathrm{L}$ ) and mild leukocytosis (total white cell count $\left.11.22 \times 10^{9} / \mathrm{L}\right)$. Serum electrolytes, calcium, phosphate and liver function tests were normal. A chest roentgenogram showed right upper lobe segmental collapse. Left humerus X-ray showed a lytic lesion and periosteal reaction of the upper one third of the humerus. Computed tomography (CT) of the thorax confirmed right upper lobe mass with right apical segmental collapse and mediastinal lymphadenopathy. Multiple lung nodules in both lung fields and a left breast lump were also seen (Figure 1). CT of the abdomen and pelvic region were normal. MRI of the humerus revealed a focal lesion in the upper left humerus with extra-medullary extension 
suggestive of malignancy. Fine Needle Aspiration Cytologycal (FNAC) examination of the breast lump and cervical lymph node confirmed adenocarcinoma of lung cancer as a primary tumour which was supported by the immunohistochemical staining. Thyroid transcription factor-1 (TTF-1) and cytokeratin (CK) 7 were consistently positive in the left breast lump, left post-auricular swelling and right submandibular lymph node, while stains for CK20, Estrogen receptor, Progesterone receptor and thyroglobulin were negative (Figure 2). The patient defaulted follow up and opted for traditional treatment. She succumbed to advanced lung cancer 4 months after diagnosis.
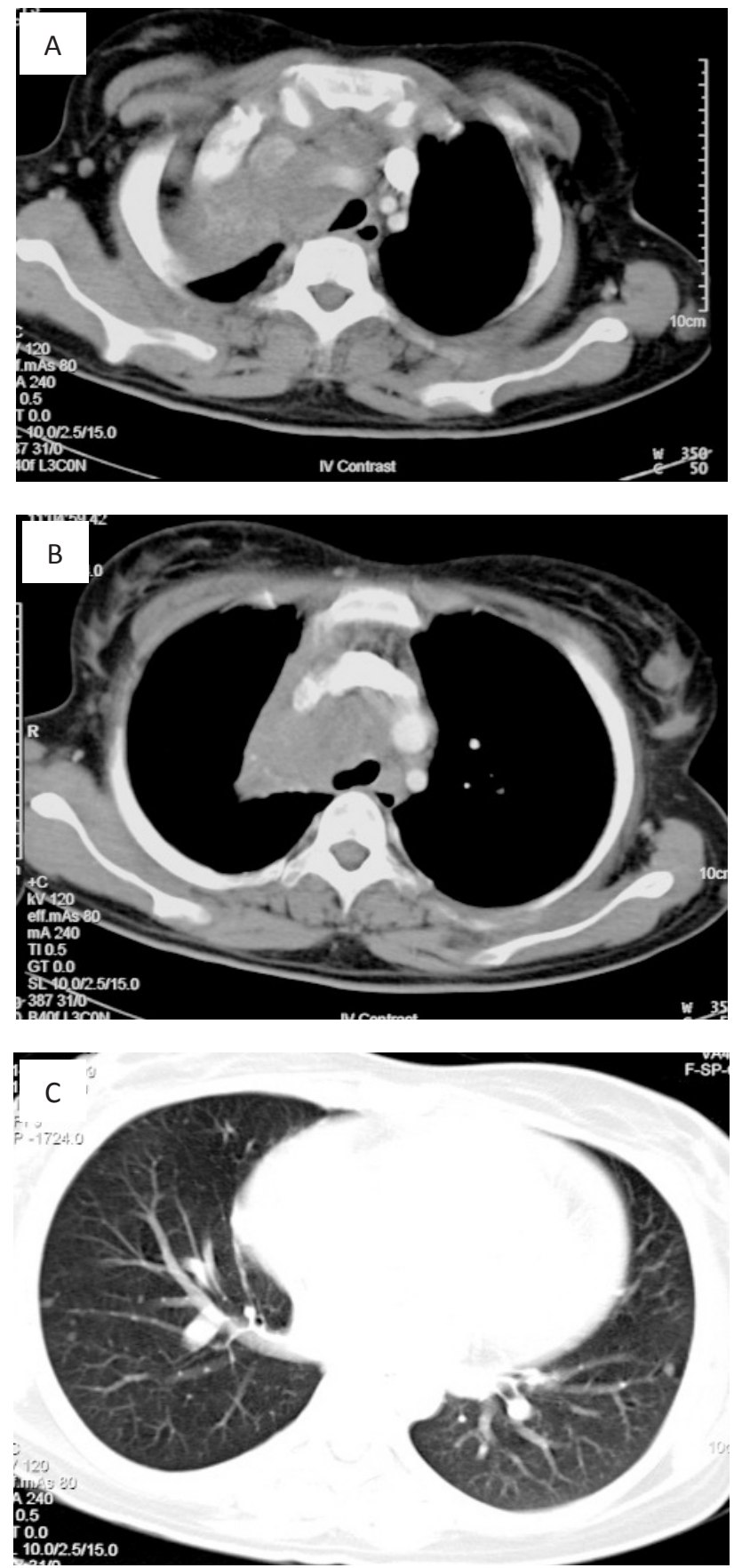

Figure 1: Computed tomography thorax showed right upper lobe mass with associated upper lobe collapse $(A)$, multiple mediastinal lympadenopathy and left breast mass (B) and multiple lung nodules (C).
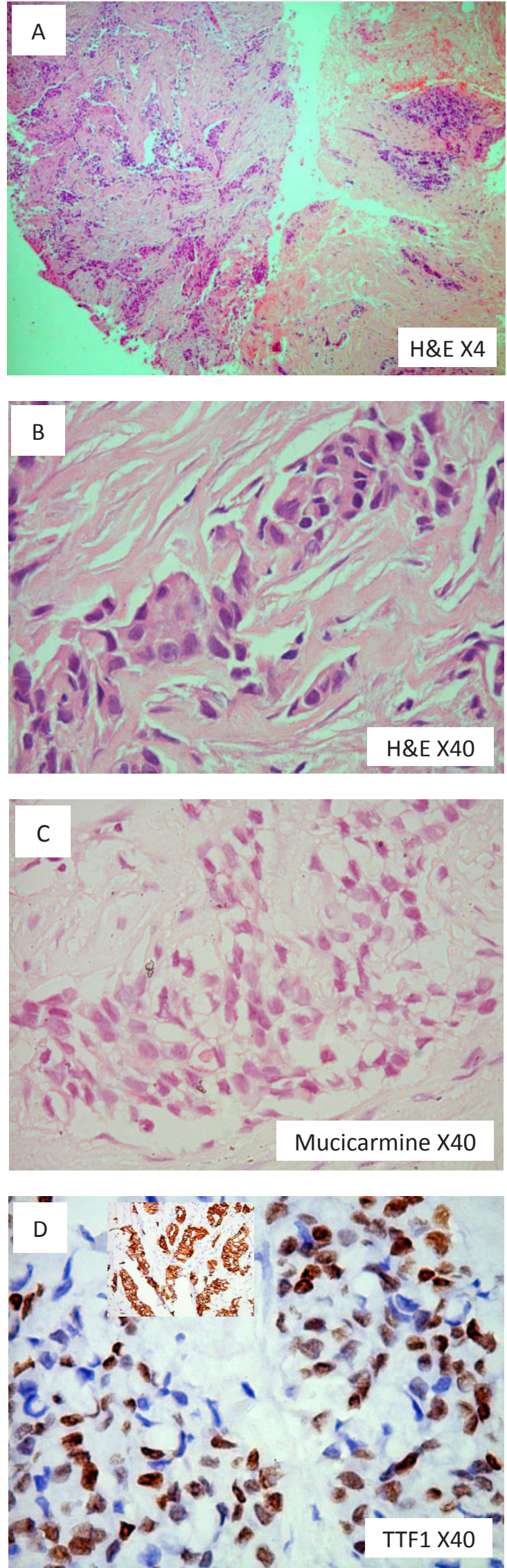

Figure 2: Biopsy of the left breast lump showed islands of infiltrating malignant cells $(A)$ with poorly formed glandular structures (B). Scattered cells showed intracytoplasmic mucin, arrow (C). The tumour cells were positive for CK7 (insert) and TTF-1(D) 


\section{Discussion}

Breast metastases from non-mammary tumours are rare, which account for $0.5 \%$ to $1.3 \%$ of all breast cancers (2). Tumours most commonly metastasising to the breast are malignant melanoma, lymphoma, and leukaemia (3). The usual sites of distant metastasis for lung cancer are liver, bone, brain, lung and adrenal gland (3). Breast metastasis from lung primary is unusual. The characteristic of some cases are summarised in Table 1. It is noteworthy that the patient in our case report is only 22 years old, which makes her the youngest patient ever reported to have breast metastasis from lung cancer. Based on the published case reports on lung cancer metastasised to the breast, the ages of the patients ranged from 39 to 81 years old (1-7). Clinically, it can be difficult to differentiate a benign from a malignant breast lump. A number of "classic" characteristics of breast cancerous lesions have been described such as single lesion, hard, immovable, irregular borders and size $\geq 2 \mathrm{~cm}$. However, these features individually do not distinguish well between cancers and benign lesions because a significant number of malignant lesions were soft or cystic (38 percent), freely movable (61 percent), regular (41 percent), and less than $2 \mathrm{~cm}$ in size (28 percent) in the study conducted by Venet et al (8). Direct involvement of the underlying chest wall or skin with oedema (including peau d'orange) or ulceration or satellite skin nodules confined to the same breast or dimpling or nipple retraction connote locally advanced breast tumour (9). The physical examination had a positive predictive value of 73 percent and a negative predictive value of 87 percent for breast cancer (10).

The majority of the case reports published previously revealed that the breast lump appears benign clinically.
The metastatic breast lump was usually described as single or multiple discrete masses, non-tender in nature with the size ranging from $0.8 \mathrm{~cm}$ to as large as $6 \mathrm{~cm}$ in diameter. The majority of the metastatic lumps were situated in the outer quadrant of the breast, which likely represented haematogenous spread $(2,3,4,7)$. All cases of breast metastasis were confirmed by histo-pathological examination (HPE) of the excision biopsy or fine needle aspiration cytology (FNAC) and/or immunohistochemical profile. It may be difficult also to differentiate a primary breast cancer from a metastatic disease. An incorrect diagnosis can lead to unnecessary surgical intervention. Therefore, any suspicious lump should be biopsied to confirm the nature of the mass. HPE with immunohistochemical test is a key point for diagnosis as all cases were confirmed in this manner. Immunohistochemical test is very helpful to differentiate the site of the primary tumour. In our patient, the diagnosis was made through immunohistochemical test and FNAC. Ideally, tissue from both lung nodules should be sampled for morphology and immunohistochemical profile comparison, but the patient was lost to follow up. To our knowledge, there is no reported TTF-1 positivity in primary breast carcinoma (11-14). Thorough morphologic assessment together with support from panels of immunohistochemical stains and special stains are able to indicate the most likely primary source of malignancy.

In conclusion, breast metastasis should always be considered in a patient with lung cancer presenting with a breast lump. The ultimate diagnosis of breast metastasis should involve histopathological confirmation of biopsy or FNAC specimens with the help of immunohistochemical test. It is important to distinguish a primary breast cancer from a metastasis to the breast, as the therapeutic planning and the outcome between them are different.

Table 1: Summary of the reported cases of breast metastasis from lung cancer

\begin{tabular}{|c|c|c|c|c|c|c|c|c|c|c|}
\hline \multirow[t]{2}{*}{ Author } & \multirow[t]{2}{*}{ Cell type } & \multirow[t]{2}{*}{ AGE } & \multirow[t]{2}{*}{ Gender } & \multicolumn{4}{|c|}{ Clinical feature of the breast lump } & \multirow[t]{2}{*}{ Diagnosis by } & \multirow{2}{*}{$\begin{array}{l}\text { Prognosis } \\
\text { (survival } \\
\text { since } \\
\text { diagnosis) }\end{array}$} & \multirow[t]{2}{*}{ Treatment } \\
\hline & & & & Location & Feature & $\begin{array}{c}\text { Skin } \\
\text { changes }\end{array}$ & $\begin{array}{l}\text { Axilarry } \\
\text { LN }\end{array}$ & & & \\
\hline $\begin{array}{l}\text { Rimner A et } \\
\text { al (1) }\end{array}$ & Large cell & 49 & Female & $\begin{array}{l}\text { Superior } \\
\text { outer } \\
\text { quadrant of } \\
\text { left breast }\end{array}$ & $\begin{array}{l}\text { Mass } 6 \times 5 \times 4 \mathrm{~cm} \text {, } \\
\text { with mastitis, no } \\
\text { axillary LN }\end{array}$ & nil & nil & Biopsy (HPE) & 7 months & $\begin{array}{l}\text { Palliative } \\
\text { radiotherapy }\end{array}$ \\
\hline $\begin{array}{l}\text { Rimner A et } \\
\text { al (1) }\end{array}$ & Adenocarcinoma & 81 & Female & $\begin{array}{l}\text { Medial and } \\
\text { lateral left } \\
\text { breast }\end{array}$ & $\begin{array}{l}\text { Multiple masses, } \\
\text { painless, hard. up } \\
\text { to } 4 \times 1.2 \times 1.9 \mathrm{~cm}\end{array}$ & nil & Palpable & $\begin{array}{l}\text { FNAC (HPE and } \\
\text { immunohistochemistry) }\end{array}$ & - & $\begin{array}{l}\text { Palliative } \\
\text { radiotherapy }\end{array}$ \\
\hline $\begin{array}{l}\text { Sadikot RT } \\
\text { et al (2) }\end{array}$ & NSCLC & 47 & Female & $\begin{array}{l}\text { Left upper } \\
\text { outer } \\
\text { quadrant }\end{array}$ & $\begin{array}{l}2 \text { discrete, non } \\
\text { tender, mobile } \\
\text { lumps }\end{array}$ & nil & nil & FNAC & - & - \\
\hline $\begin{array}{l}\text { Gomez-Caro } \\
\text { et al (3) }\end{array}$ & Adenocarcinoma & 65 & Male & Left breast & Single mass & nil & nil & $\begin{array}{l}\text { FNAC (HPE and } \\
\text { immunohistochemistry) }\end{array}$ & - & $\begin{array}{l}\text { Radical } \\
\text { mastectomy } \\
\text { followed by } \\
\text { chemotherapy }\end{array}$ \\
\hline $\begin{array}{l}\text { Luh SP } \\
\text { (7) }\end{array}$ & SCLC & 66 & Female & $\begin{array}{l}\text { Left upper } \\
\text { and lower } \\
\text { quadrant }\end{array}$ & $\begin{array}{l}2 \text { discrete masses } \\
(3 \text { and } 0.8 \mathrm{~cm}) \text {, firm }\end{array}$ & nil & palpable & $\begin{array}{l}\text { Excision biopsy } \\
\text { (HPE and } \\
\text { immunohistochemistry) }\end{array}$ & - & $\begin{array}{l}\text { Left } \\
\text { mastectomy }\end{array}$ \\
\hline
\end{tabular}




\section{References}

1. Georgiannos SN, Aleong JC, Goode AW, Sheaff M. Secondary neoplasms of the breast. A survey of the 20th century. Cancer 2001; 92: 2259-66.

2. Rimner A, Rosenzweig KE. Palliative radiation for lung cancer metastases to the breast: Two case reports. $J$ Thorac Oncol 2007; 2: 1133-35.

3. Sadikot RT, Renwick DS, Dacosta P, Chalmers AG, Pearson SB. Breast metastasis from non-small cell lung cancer. Southern Med J 1997; 90: 1063-64.

4. Gomez-Caro A, Pinero A, Roca MJ, Ferri B, Galindo PJ, Parrilla P. Surgical treatment of solitary metastasis in the male breast from non-small cell lung cancer. Breast J 2006; 12: 366-67.

5. Masmoudi A, Mathieu MC, Soria JC. Breast metastasis from lung adenocarcinoma: a case report. Anticancer Res 2003; 23: 1825-6.

6. Babu KS, Robert F, Bryden F, McCafferty A, Downer P, Hansell DT et al. Metastases to breast from primary lung cancer. J Thorac Oncol 2009; 4: 540-2.

7. Luh SP, Kuo C, Tsao TC. Brest metastasis from small cell lung cancer. J Zhejiang Univ Sci B 2008; 9: 39-43.

8. Venet L, Strax P, Venet W, Shapiro S. Adequacies and inadequacies of breast examinations by physicians in mass screening. Cancer 1971; 28: 1546.
9. Gueth $U$, Wight E, Schoetzau A, Langer I, Dieterich H, Rochlitz $\mathrm{C}$ et al. Non-inflammatory skin involvement in breast cancer, histologically proven but without the clinical and histological T4 category features. J Surg Oncol 2007; 95: 291-7.

10. van Dam PA, Van Goethem ML, Kersschot E, Vervliet J, Van den Veyver IB, De Schepper A et al. Palpable solid breast masses: Retrospective single and multimodality evaluations of 201 lesions. Radiology 1988; 166: 435-9

11. Matosa A, Singh K, Jacob R, Greaves WO, Tavares R, Noble $L$ et al. Comparison of thyroid transcription factor-1 expression by 2 monoclonal antibodies in pulmonary and nonpulmonary primary tumors. Appl Immunohistochem Mol Morphol 2010; 18: 142-9.

12. Moldvay J, Jackel M, Bogos K, Soltesz I, Agocs L, Kovacs $\mathrm{G}$ et al. The Role of TTF-1 in differentiating primary and metastatic lung adenocarcinomas. Pathology Oncology Research 2004; 10: 85-8.

13. Stenhouse G, Fyte N, King G, Kerr KM. Thyroid transcription factor-1 in pulmonary adenocarcinoma. J Clin Pathology 2004; 57: 383-87.

14. Zhu W, Michael CW. WT1, Monoclonal CEA, TTF-1, and CEA antibodies in the differential diagnosis of lung, breast, and ovarian adenocarcinomas in serous effusions. Diagnostic Cytopathology 2007; 35: 370-75. 